\title{
Implementasi Emotional Intelligence Dalam Pelaksanaan Supervisi Pengajaran Kepala Sekolah Untuk Meningkatkan Semangat Kerja Profesional Guru
}

\author{
Nur Ali Rahman \\ Stat Pengajar Fak. Tarbiyah UIN Malang, \\ Peserta Program Doktor UM Malang
}

\begin{abstract}
One of the principal's responsibility toward teacher is improving teachers' capability in managing teaching learning process in the school. Therefore, he must hold supervision perfectly. In fact, in many cases indicate that the principal, in general, who holds the duties of supervision in the school were not incertert with the principles of supervision yet. The methods used by the principal were less persuasive, whereas the appropriate methode can determine the success supervision, because the activities of supervision are related with social interaction between supervisor and teachers.

This article describes about individual's emotional intelligence that has influence in achieving the goals. Someone who has a high emotional intelligence is more success in his works, can develop a good personal relation, and motivate other people and him self. The principal's emotional intelligence has influence toward achievement of his works significantly. The principal who has a high emotional intelligence is more success in holding supervision and duties, can develop a personal-interpersonal relations and motivate the teachers and himself well.
\end{abstract}

Kata Kunci: Emotional Intelligence, Empati, dan Supervisi Pengajaran. 


\section{A. Pendahuluan}

Tinggi rendahnya mutu pendidikan banyak dipengaruhi oleh kualitas proses pembelajaran yang dilakukan oleh guru. Untuk itu, peningkatan kemampuan guru dalam mengelola kegiatan pembelajaran di sekolah menjadi tanggungjawab kepala sekolah sebagai supervisor, pembina dan atasan langsung. Karena itu ia harus melaksanakan supervisi secara baik dan benar sesuai dengan prinsip-prinsip supervisi serta teknik dan pendekatan yang tepat.

Supervisi yang dilakukan kepala sekolah, antara lain untuk meningkatkan kompetensi guru-guru dalam kegiatan belajar mengajar, sehingga diharapkan dapat memenuhi misi pengajaran yang diembannya, atau misi pendidikan nasional dalam lingkup yang lebih luas. Sebagai-mana kita pahami bersama bahwa masalah profesi guru dalam mengemban kegia-tan belajar mengajar akan selalu ada dan terus berlanjut seiring dengan kemajuan ilmu pengetahuan dan teknologi, sehingga bimbingan dan pembinaan yang profesional dari kepala sekolah selalu dibutuhkan guru secara berkesinambungan. Pembinaan tersebut, disamping untuk meningkatkan semangat kerja guru, juga diharapkan dapat memberi dampak positif terhadap munculnya sikap profesional guru ${ }^{1}$. Karena itu sepervisi yang dilakukan oleh kepala sekolah memiliki dampak positif dalam menumbuhkan dan mengembangkan profesi guru, baik secara langsung maupun tidak langsung.

Kenyataan di lapangan menunjukkan bahwa pada umumnya para kepala sekolah sebagai supervisor dalam melaksanakan supervisi belum sesuai dengan prinsip-prinsip supervisi dan kebanyakan pendekatannya kurang persuasive, padahal cara pendekatan yang tepat sangat menentukan keberhasilan supervisi, karena kegiatan ini menyangkut interaksi sosial antara supervisor dengan guru.

Hasil penelitian Pidartá ${ }^{2}$ menunjukkan bahwa pembinaan oleh kepala sekolah dalam rangka peningkatan profesi guru belum mencapai sasaran sebagaimana yang diharapkan, dalam arti tidak memberikan dukungan secara sistematis pada kerja guru. Senada dengan itu, hasil penelitian Lipham, Rankin dan Hoch dalam Hadi, S. ${ }^{3}$ menunjukkan bahwa para guru menyatakan, kepala sekolah sebagai supervisor tidak sepenuhnya mampu melaksanakan program pengembangan dan peningkatan ketenagaan kependidikan di sekolah, karena secara teknis ia tidak kompeten dalam semua bidang studi. Dengan kata lain bahwa seorang supervisor belum tentu menguasai bidang studi yang berbeda, 
meskipun terdapat pula bebera-pa guru yang memiliki bidang studi yang sama. Oleh karena itu, menurut Pidarta ${ }^{4}$ seyogyanyalah supervisor memiliki kompetensi yang sama dengan guru, hanya bobotnya harus lebih tinggi. Namun, kondisi tersebut sulit dite-mui, dengan kata lain tidak semua bidang studi dikuasai oleh kepala sekolah sebagai supervisor. Seba-liknya faktor dari para guru terutama para guru yang kurang mampu dan merasa malu untuk menghadap kepala sekolah juga menjadi kendala pelaksanaan supervisi pengajaran. Kondisi seperti ini dapat dimengerti karena ada beberapa orang guru merasa segan meminta bantuan secara langsung kepada kepala sekolah, sebaliknya mereka merasa lebih senang meminta bantuan kepada teman sekerjanya yang memiliki kemampuan lebih baik dari dirinya.

Kenyataan di atas mengindikasikan bahwa pelaksanaan supervisi pengajaran kepala sekolah belum dapat berjalan secara optimal, di samping itu, realitas di atas juga mengindikasikan bahwa proses pembinaan yang dilakukan oleh kepala sekolah sebagai supervisi untuk membantu guru belum dapat berjalan secara efektif. Untuk itu perlu dicarikan cara pemecahannya sehingga kepaia sekolah dapat melaksanakan tugasnya sebagai supervisi pengajaran secara optimal.

Berdasarkan data penelitian di atas ditemukan beberapa problem yang muncul pada kegiatan pelaksanaan supervisi kepala sekolah yaitu;

1. Pendekatan yang digunakan kepala sekolah kurang persuasive, padahal pendekatan dapat menentukan tingkat interaksi sosial antara supervisor dengan guru.

2. Pembinaan yang dilakukan oleh kepala sekolah kepada guru belum mencapai sasaran, karena kepala sekolah secara teknis kurang kompeten dalam semua bidang studi. Kepala sekolah belum tentu menguasai bidang studi yang sedang disupervisi.

3. Guru yang kurang mampu dalam mengelola kegiatan belajar mengajar merasa malu untuk meminta bantuan secara langsung kepada kepala sekolah.

4. Guru lebih senang meminta bantuan kepada teman sejawat yang memiliki kemampuan lebih baik darinya dari pada ke kepala sekolah,

Berdasarkan pada uraian di atas, maka permasalahannya adalah bagaimana sebaiknya kepala sekolah sebagai supervisor pengajaran melaksanakan tugasnya secara efektif dalam membantu guru meningkatkan kemampuan 
pengelolaan kegiatan pembelajaran secara professional?. Untuk memperoleh jawaban pertanyaan itu, dalam tulisan ini dibahas; (1) Orientasi, pendekatan supervisi kepala sekolah dan Emotional Intelligence, (2) Implementasi emotional intelligence dalam pelaksanaan supervisi kepala sekolah, dan (3) Strategi peningkatan kualitas pelaksanaan supervisi pengajaran kepala sekolah..

\section{B. Pembahasan}

\section{Supervisi Pengajaran Kepala Sekolah dan Emotional Intelligence}

a) Orientasi dan Pendekatan Supervisi Pengajaran

Pembinaan kepada guru merupakan bentuk bantuan professional yang diberikan oleh kepala sekolah dalam supervisi pengajaran. Kegiatan ini dilakukan untuk meningkatkan kemampuan profesionalisme para guru, terutama kemampuan mengelola kegiatan belajar mengajar. Glickman ${ }^{5}$ membagi orientasi supervisi pengajaran menjadi tiga berdasarkan kemampuan guru yaitu; (1) direktif, (2) nondirektif, dan (3) kolaboratif. Pertama, orientasi direktif diterapkan manakala supervisor menemukan guru yang dalam mengembangkan dirinya sendiri sangat rendah, sehingga pembina harus banyak memberikan petunjuk dengan contohcontoh kongrit disertai dengan tugas-tugas. Kedua, orientasi non-direktif digunakan apabila tanggungjawab guru dalam mengembangkan dan membina dirinya sendiri tinggi. Pembina hanya sekedar fasilitator. Ketiga, orientasi kolaboratif digunakan apabila tanggungjawab antara guru dengan supervisor seimbang. Pembina bersama-sama saling memberi dan saling meminta melalui diskusi, sehingga diperoleh kesepakatan.

Oliva $^{6}$ membagi orientasi supervisi menjadi dua yaitu; (1) orientasi langsung, dan (2) tidak langsung. Pertama, orientasi langsung didasarkan pada asumsi bahwa (i) pengawasan dilakukan atas dasar kewenangan seseorang yang memiliki posisi dalam hirarkhi organisasi, (ii) orang yang lebih tinggi dan ahli, (iii) penghargaan yang penting adalah eksternal terutama dari atasan, (iv) bekerja itu sifatnya rasional sehingga dalam supervisi tidak perlu membicarakan perasaan dan hubungan antar pribadi. Kedua, orientasi tidak langsung didasarkan pada asumsi bahwa; (i) pengawasan terhadap situasi tergantung pada tuntutan masalah, (ii) Keahliann didasarkan pada ilmu dan pengalaman bukan pada jabatan, (iii) 
hasil kerja guru merupakan alat evaluasi terbaik bagi pengukuran performansi, (iv) penghargaan instrinsik adalah penting disamping penghargaan ekstrinsik, (v) guru harus didengar dan dipahami oleh supervisor, (vi) bekerja tidak hanya rasional tetapi juga emosional, (vii) perlu penyelesaian masalah secara kolaboratif.

Sergiovanni ${ }^{\top}$ membedakan pendekatan supervisi pengajaran menjadi tiga yaitu; (1) pendekatan ilmiah, (2) pendekatan artistic, dan (3) pendekatan klinis. Pendekatan ilmiah berpandangan bahwa pengajaran dipandang sebagai ilmu. Karena itu perbaikan pengajaran harus dilakukan dengan menggunakan metodemetode ilmiah, yaitu merumuskan masalah berdasrkan kerangka teori pengajaran, menyusun hipotesis, mengumpulkan data, menganalisis data dengan menggunakan teknik analisis yang relevan, menguji hipotesis dan menarik kesimpulan. Pendekatan artistic merekomendasikan agar pembina turut mengamati, merasakan dan mengapresiasi pengajaran yang dilakukan oleh guru. Pembina harus mengikuti mengajar guru dengan cermat, telaten dan utuh. Sedangkan pendekatan klinis diangkat dari model hubungan diagnosis terapi dalam melaksanakan pembinaan guru. Dalam pendekatan klinis pembinaan dilakukan secara kolegial antara pembina dengan guru. Melalui hubungan kolegial atau sejawat diharapkan kemampuan mengajar guru dapat ditingkatkan.

Dari berbagai orientasi dan pendekatan di atas tampak bahwa pada hakikatnya kegiatan supervisi melibatkan hubungan antara manusia yang satu dengan yang lain, yaitu supervisor dengan guru untuk mencapai suatu tujuan. Karena keterkaitannya dengan pola hubungan antar manusia itulah maka sulit untuk dilepaskan dari sikap, motivasi, emosi dan tata nilai yang dianut oleh dua orang atau lebih yang berinteraksi. Untuk itu dalam pelaksanaan supervisi pengajaran Kepala Sekolah diperlukan penerapan Emotional Intelligence terutama domain kecakapan sosial Goleman ${ }^{8}$ atau dengan istilah Gardner ${ }^{y}$ Inteligensi antarpersonal.

\section{b) Emotional Intelligence}

Emotional intelligence adalah kemampuan untuk menyadari diri sendiri, memotivasi diri, mengatur diri sendiri, empati dan membina hubungan dengan orang lain atau disebut dengan istilah lain keterampilan social Goleman ${ }^{10}$. Kemampuan dalam menyadari diri sendiri, memotivasi diri dan mengatur diri sendiri dimasukkan dalam kategori kecakapan pribadi yaitu kecakapan untuk 
menentukan bagaimana seseorang atau kita mengelola diri sendiri (interpersonal), Sedangkan kemampuan dalam berempati dan membina hubungan dengan orang lain dimasukkan dalam kategri kecakapan sosial yaitu kecakapan untuk menentukan bagaimana seseorang atau kita menangani suatu hubungan dengan orang lain. Gardner ${ }^{11}$ menyebut dengan istilah inteligensi aniarpersonal yaitu kemampuan untuk memahami orang lain; apa yang memotivasi mereka, bagaimana mereka bekerja, bagaimana bekerja bahu membahu dengan mereka. Dengan demikian, maka dapat dikatakan bahwa seseorang yang memiliki emotional intelligence cukup bagus, maka ia memiliki kecakapan dalam mengetahui dan menangani perasaannya sendiri serta mampu membaca dan menghadapi perasaan orang lain secara efektif serta memilikikeuntungan dalam setiap bidang kehidupan karena mampu bekerja sama dengan orang lain

Menurut Goleman ${ }^{12}$ Empati merupakan unsur pokok emotional intelligence yang memiliki peranan penting dalam kehidupan social manusia. Kemampuan berempati yaitu kemampuan seseorang untuk memahami perasaan orang lain. Empati dibangun berdasarkan kesadaran diri. Semakin terbuka kita kepada emosi diri sendiri, semakin terampil pula kita membaca perasaan orang lain. Hal ini mengisyaratkan bahwa empai menjadi factor yang sangat menentukan keberhasilan seseorang untuk mencapai prestasi terutama dalam kelompok social seperti misalnya seseorang yang menjadi anggota dari ikatan guru di sekolah, seseorang menjadi anggota suatu organisasi tertentu, dan atau supervisi pengajaran dll. Dengan dimilikinya empati, maka seseorang dapat membaca dan memahami perasaan-perasaan sesama anggota kelompok lainnya, dan selanjutnya ia dapat menempatkan diri secara proporsional di dalam kelompok tersebut, dan biasanya situasi seperti ini akan membantu orang dalam berkomunikasi dengan baik dan mencapai sukses.

\section{Implementasi Emotional Intelligence dalam Pelaksanaan Supervisi Pengajaran Kepala Kekolah}

Tujuan utama pendidikan adalah mengembangkan kemampuan, pengetahuan, keterampilan dan sikap anak didik secara optimal. Banyak instrumen yang mempengaruhi keberhasilan pendidikan diantaranya, ketersediaan sumber belajar yang handal, adanya bahan belajar yang relevan, tersedianya sarana dan 
prasarana yang memadai, terciptanya suasana yang kondusif didukung dengan pembiayaan yang mencukupi. Diantara instrumen tersebut di atas, yang sangat berpengaruh adalah kepemimpinan kepala sekolah terutama supervisi pengajarannya kepada para guru. Kepala sekolah sebagai supervisor pada intinya adalah mengajak para guru dan tenaga kependidikan lainnya untuk menjalankan tugas kependidikan secara efektif. Ketidak mampuan kepala sekolah menjalin hubungan antar pribadi dapat membuat kinerja setiap orang rendah, seperti misalnya memunculkan permusuhan dan apatis, menurunkan motivasi, kurang dapat dipercaya, dan lain-lainnya. Kekuatan dan kelemahan kepala sekolah dalam emotional intelligence (kecakapan pribadi dan kecakapan sosial) dapat diukur antara lain dari suasana kondusif atau tidak dari sekolah yang dipimpinnya. Karena suasana sekolah sangat berpengaruh terhadap kegiatan belajar mengajar yang pada gilirannya nanti berpengaruh juga pada prestasi belajar siswa. Indikator suasana sekolah dan belajar, diantaranya mencakup; komunikasi yang transparan, fleksibilitas dalam proses pembelajaran, kesempatan menemukan inovasi, rasa kepemilikan dan tanggung jawab terhadap proses pendidikan, dan penetapan standar belajar yang tinggi.

Pola pendekatan supervisi kepala sekolah juga sangat berpengaruh terhadap kinerja para guru dan keberhasilan belajar siswa. Sekolah yang dipimpin oleh kepala sekolah yang memiliki pola direktif kurang efektif dalam pelaksanaan supervisi. Hasil penelitian Hadi ${ }^{13}$ mengenai kefektifan guru dan keefektifan pola pendekatan supervisi kepala sekolah menunjukkan bahwa sebagian besar guru-guru STM se-Malang mempunyai persepsi bahwa pola pendekatan supervisi kolaboratif dan non-direktif merupakan pola yang paling efektif yang dapat diterapkan oleh kepala sekolah. Pola direktif kurang efektif menurut persepsi sebagian besar guru. Hasil-hasil penelitian di Amerika mengenai 3 model supervisi tersebut menunjukkan bahwa guru-guru lebih berpikir positif jika kepala sekolahnya menerapkan model supervisi kolaboratif dan non-direktif Blumnerg ${ }^{14}$. Senada dengan hal itu, hasil penelitian Nursalim, M. ${ }^{15}$ juga menunjukkan bahwa tinggi rendahnya keterampilan mengajar guru banyak dipengaruhi oleh kepala sekolah sebagai supervisor bukan sebagai administrator.

Berkaitan dengan peran penting kepala sekolah itu, Mayer dalam Nursalim $M{ }^{16}$ menyatakan bahwa keberhasilan kepala sekolah bergantung pada tanggungjawabnya kepada kejadian sehari-hari di sekolah. Kepala sekolah perlu 
berempati kepada para guru, staf dan anggota timnya. Kepala sekolah juga dituntut mampu mengemukakan harapannya berkaitan dengan masalah-masalah yang dihadapi supaya lebih baik dikemudian hari. Dalam kaitannya dengan empati ini, Goleman menyatakan bahwa empati merupakan salah satu kecakapan sosial yang perlu dimiliki oleh seseorang yang pekerjaanya berkaitan dengan orang lain. Sedangkan kemampuan berempati antara pria dan wanita berbeda-beda. Hasil penelitian Goleman tentang gender dan empati menunjukkan bahwa (i) wanita lebih cenderung mengalami penyesuaian perasaan (berempati) terhadap orang lain dari pada pria, (ii) wanita lebih baik dalam mendeteksi perasaan yang disembunyikan orang lain dari pada pria.

Dengan demikian, kepala sekokah sebagai supervisor pengajaran yang berhubungan dengan para guru yang cukup variatif perlu memiliki kecakapan sosial yang berupa "empati" yang merupakan salah satu dari emotional intelligence. Dengan dimilikinya empati, maka kepala sekolah dapat membaca dan memahami perasaan-perasaan para guru yang disupervisi dan tenaga kependidikan lainnya, dan selanjutnya ia dapat menempatkan diri secara proporsional di dalam kelompok tersebut. Kondisi yang demikian itu memungkinkan seseorang dapat berkomunikasi dengan baik dan mencapai sukses.

Implementasi "empati" dalam supervisi pengajaran kepala sekolah dapat dilakukan dengan cara antara lain

(1) menghayati dunia perasaan guru yang disupervisi serta dapat melihat dunia luar menurut pola acuan guru

(2) mengkomunikasikan penghayatannya dengan menunjukkan bahwa dirinya memahami perasaan, tingkahlaku, dan pengalaman guru yang disupervisi secara pribadi.

Secara teknis penerapan empati dalam supervisi pengajaran Kepala Sekolah dapat dilakukan dalam bentuk antara lain; yaitu;

(1) mendeskripsikan perasaan yang diungkapkan guru yang disupervisi

(2) menghayati perasaan dan emosi sendiri

(3) menghayati dan mengidentifikasi perasaan guru yang disupervisi

(4) mengidentifikasi pengalaman dan tingkahlaku guru yang disupervisi

Implementasi "empati" yang merupakan salah satu domain dalam Emotional Intelligence (EI) ikut berperan dalam pencapaian prestasi kerja. 
Penelitian yang dilakukan Cooper menyebutkan bahwa orang yang tingkat Emotional Intelligence -nya tinggi, lebih berhasil dalam pekerjaannya, dapat membangun hubungan personal dengan baik, dan dapat memotivasi dirinya dan orang lain. Cooper juga mengemukakan bahwa orang yang memiliki EI tinggi dapat meningkatkan kekuatan intuisi, senantiasa percaya dan dipercaya orang lain, memiliki integritas, dapat menemukan solusi pemecahan masalah dalam keadaan darurat, sehingga dapat melakukan kepemimpinan secara efektif. Menurut Goleman ${ }^{17}$ Domain Emotional Intelligence yang paling sering mengantar orang berhasil yaitu; inisiatif, semangat juang (motivasi) dan kemampuan menyesuaikan diri, kemampuan memimpin tim, percaya diri dan empati

Hasil-hasil penelitian di atas menunjukkan bahwa semakin baik EI seseorang, semakin efektif dalam melaksanakan pekerjaannya. Gilmore ${ }^{18}$ Fromn, E.M. ${ }^{19}$ menyatakan bahwa individu yang produktif memiliki ciri-ciri sebagai berikut; (1) tindakannya konstruktif, (2) memiliki kepercayaan diri, (3) bertanggung jawab, (4) memiliki rasa cinta terhadap pekerjaan (empati), (5) mempunyai pandangan ke depan, (6) kreatif, imajinatif dan inovatif. Cici-ciri orang produktif itu, pada hakikatnya sudah masuk ke dalam Emotional Intelligence. Dengan demikian, untuk menjadi orang yang produktif, perlu memiliki emotional intelligence.

\section{Strategi Peningkatan Kualitas Supervisi Pengajaran Kepala Sekolah}

Beradasarkan pada hasil-hasil penelitian di atas, maka persoalan-persoalan yang muncul terkait dengan pelaksanaan supervisi pengajaran kepala sekolah dapat disimpulkan menjadi; (1) Pendekatan yang digunakan kepala sekolah kurang persuasive, padahal pendekatan yang digunakan oleh kepala sekolah dalam melakukan supervisi dapat menentukan tingkat interaksi sosial antara supervisi dengan guru. (2) Pembinaan yang dilakukan oleh kepala sekolah kepala kepada guru belum mencapai sasaran, karena kepala sekolah secara teknis kurang kompeten dalam semua bidang studi. Kepala sekolah belum tentu menguasai bidang studi yang berbeda. (3) Guru yang kurang mampu dalam mengelola kegiatan belajar mengajar merasa malu untuk meminta bantuan secara langsung 
kepada kepala sekolah. (4) Guru lebih senang meminta bantuan kepada teman sejawat yang memiliki kemampuan lebih baik darinya dari pada ke kepala sekolah.

Untuk menyelesaikan persoalan-persoalan di atas, ada beberapa strategi yang bisa dilakukan untuk meningkatkan kualitas pelaksanaan supervisi pengajaran kepala sekolah, diantaranya;

\section{Mengembangkan Kurikulum Diklat}

Berdasarkan pada pengamatan penulis ketika terlibat dalam penataran dan diklat berkaitan dengan kepala sekolah dan supervisi selama ini, materi penataran yang selama ini disampaikan muatannya banyak yang bersifat administratif dengan pendekatan proyek. Jika keadaan ini terus berlanjut, maka sulit kiranya bagi kepala sekolah dan guru untuk bisa menyelesaikan persoalan-persolan yang terkait dengan supervisi pengajaran kepala sekolah. Kondisi ini akan berdampak pada kualitas supervisi pengajaran, proses belajar mengajar guru dan hasil prestasi belajar siswa.

Untuk itu perlu ada pengembangan materi penataran atau diklat dan Nara sumber. Dari aspek Materi perlu ada pengembangan materi, diantaranya yaitu; (i) multiple intelligence (MI), (ii) emotional intelligence (EI), dan implementasi MI dan EI dalam pembelajaran di sekolah. Dari aspek Nara sumber yaitu; (i) dari kalangan akademisi, dan (ii) dari kalangan kedokteran atau dokter yang mendalami bidang kependidikan dan pembelajaran.

Pemikiran itu didasarkan pada pengalaman penulis selama mengikuti perkuliahan dan diskusi kelas yang diasuh oleh Bapak Prof. Dr. T. Raka Joni, dan Ibu Dr. dr. Lusiana, M.Pd. dan ketika terjun di lapangan berkaitan dengan penataran dan diklat selama ini. Pengalaman yang didapatkan selama proses perkuliahan ini banyak mewarnai pola pikir penulis untuk melakukan inovasiinovasi terutama berkaitan dengan pembelajaran dan penataran atau diklat.

\section{Mengembangkan Model Diklat}

Model diklat dan penataran bagi para kepala sekolah dan guru yang selama ini dipakai adalah tutorial dengan metode ceramah. Model ini ternyata - menurut komentar sebagian para peserta penataran - akan menambah kesan bagi mereka bahwa diklat/penataran adalah kegiatan menghabiskan uang dan 
rutinitas serta tidak ada hal-hal baru dan inovasi. Kesan itu mengakibatkan menurunnya sengamat peserta untuk memahami materi, bahkan mengesankan kegiatan proyek - bukan kegiatan peningkatan kualitas SDM- yang pada ujung-ujungnya adalah berapa jumlah amplop yang diterima peserta. Untuk itu model-model penataran atau diklat perlu dikembangkan dengan menggunakan pendekatan CBSA dengan sentuhan-sentuhan "Multiple Intelligence" dan "Emotional Intelligence", sehingga metode simulasi, studi kasus, dan diagnosis dapat digunakan secara efektif. Contoh-contoh kasus yang ditulis oleh Gardner dan Goleman dapat dipakai sebagai perbandingan. Pengembangan model penataran itu urgen untuk dilakukan, karena secara teoritis, para kepala sekolah dan guru sudah memahamii beberapa orientasi dan pendekatan-pendekatan supervisi pengajaran.

Dengan pengembangan materi dan model itu, dimungkinkan dapat meningkatkan kualitas pelaksanaan supervisi pengajaran kepala sekolah dan semangat kerja professional guru, serta setidak-tidaknya dapat mengurangi persoalan-persoalan pelaksanaan supervisi di sekolah yang ada selama ini. Karena dengan materi dan model itu, para kepala sekolah mampu menganalisis "kapan kolaboratif, non-direktif, atau direktif" dapat digunakan sesuai dengan lokasi sekolah dan karakter para guru.

\section{Melakukan Penelitian Evaluasi}

Penelitian evaluasi ini perlu dilakukan sebagai satu kesatuan dalam kegiatan Diklat/penataran, sehingga tidak menambah kesan bagi semua pihak bahwa "selesai kegiatan semua beres". Karena itu perlu dilakukan penelitian evaluasi, meliputi; (i) evaluasi program kegiatan diklat, dan (ii) evaluasi pelaksanaan kegiatan supervisi pengajaran bagi kepala sekolah yang sudah mengikuti diklat. Kedua kegiatan evaluasi itu penting dalam upaya untuk mengatahui kelebihan dan kekurangan pelaksanaan program.

\section{Kesimpulan}

Berdasarkan uraian di atas dapat disimpulkan sebagai berikut; 
1. Pola Pendekatan supervisi Kepala Sekolah memiliki pengaruh terhadap kinerja para guru dan keberhasilan belajar siswa.

2. Tinggi rendahnya kualitas pengelolaan kegiatan mengajar guru banyak dipengaruhi oleh kualitas kepala sekolah sebagai supervisor, bukan sebagai administrator.

3. Peningkatan kualitas supervisi pengajaran kepala sekolah dapat dilakukan diantaranya melalui pengembangan kurikulum dan model diklat/penataran.

4. Emotional intelligence kepala sekolah banyak berpengaruh terhadap pencapaian prestasi kerjanya. Kepala Sekolah yang memiliki emotional intelligence tinggi, lebih berhasil dalam melaksanakan tugasnya dan dapat membangun hubungan interpersonal \& antarpersonal sera memotivasi dirinya dan para guru dengan baik.

\section{Endnotes}

1 Pidarta, M. 1992. Pemikiran tentang Supervisi Pendidikan. Jakarta: Bumi Aksara.

2 Ibid,

3 Hadi, H. 1992. Persepsi Guru STM Se-Kab. Malang tenang Kefektifan Guru dan Keefektifan Pola-pola Pendekatan Supervisi Kepala Sekolah. Tesis tidak diterbitkan, Malang: Fakultas Pascasarjana UM Malang.

4 Pidarta, M. 1992. Op.cit.

s Glickman, C.D. 1981. Developmental Supervision: Alternative Practices for Helping Teacher Improve Instruction. Alexandra: ASCD

6 Oliva, P.E, 1984. Supervision for Today Schools. New York: Longman Inc

7 Sergiovanni, T.J. 1982. Supervision of Teaching. ASCD.

* Goleman, D. (1999). Working with Emotional Intelligence. London: Bloomsbury Publishing Plc.

9 Gardner, H., 1999, Intelligence refremed: Multiple intelligences for the 21 th century, New York: Basic Books.

10 Goleman, D. 1999. op.cit.

11 Gardner, H., 1999, Op.Cit

12 Goleman, D. 1999. op.cit.

13 Gardner, H., 1999. Intelligence refremed: Multiple intelligences for the 2 I th century, New York: Basic Books. 
14 Blumberg, A. 1974. Superavision on Teacher: A Private Supervision in Seceondary School. Cambridge: Massachusets, Houghton Mifflin Company

15 Nursalim, M. 2001. Peranan Supervisi Pengajaran Kepala Sekolah, Keterampilan Mengajar Guru dan Prestasi Belajar Siswa SLTPN Kota Malang: Suatu Kajian Korelasional, Tesis tidak diterbitkan, Malang: Fakultas Pascasarjana UM Malang 16 Ibid.

17 Goleman, D. (1999). Working with Emotional Intelligence. London: Bloomsbury Publishing Plc.

18 Gilmore, J.V. 1974. The Productive Personality. San Fransisco, Albion Publishing 19 Fromn, E.M. 1975. Man for Him Self. Fawest Premier Book.

\section{Daftar Pustaka}

Blumberg, A. 1974. Superavision on Teacher: A Private Supervision in Seceondary School. Cambridge: Massachusets, Houghton Miffin Company

Fromn, E.M. 1975. Man for Him Self. Fawest Premier Book.

Gardner, H., 1999, Intelligence refremed: Multiple intelligences for the 21 th century, New York: Basic Books.

Gardner, H., 1999, The disciplined mind: What all students should understand, New York: Simon \& Schuster Inc.

Gardner, H., 1991, The unschooled mind: How children think and how schools should teach, New York: Basic Books.

Gilmore, J.V. 1974. The Productive Personality. San Fransisco, Albion Publishing Glickman, C.D. 1981. Developmental Supervision: Alternative Practices for Helping Teacher Improve Instruction. Alexandra: ASCD.

Goleman, D. (1999). Working with Emotional Intelligence. London: Bloomsbury Publishing Plc.

Gorton, R.A. 1977. School Administration. Jowa: WmC.

Hadi, H. 1992. Persepsi Guru STM Se-Kab. Malang tentang Kefektifan Guru dan Keefektifan Pola-pola Pendekatan Supervisi Kepala Sekolah. Tesis tidak diterbitkan, Malang: Fakultas Pascasarjana UM Malang. 
Nur Ali R. 2003. Inteligensi Pemimpin dan Pengaruhnya terhadap Gaya Kepemimpinannya. Makalah diskusi kelas, Malang: Fakultas Pascasarjana UM Malang.

Nursalim, M. 2001. Peranan Supervisi Pengajaran Kepala Sekolah, Keterampilan Mengajar Guru dan Prestasi Belajar Siswa SLTPN Kota Malang: Suatu Kajian Korelasional, Tesis tidak diterbitkan , Malang: Fakultas Pascasarjana UM Malang

Lusiana, 2003. Bahan Perkuliahan Psikologi Pendidikan Lanjut (DIP 711), Bahan Perkuliahan tidak diterbitkan, Malang: Fakultas Pascasarja UM Malang

Oliva, P.E, 1984. Supervision for Today Schools. New York: Longman Inc.

Owens, R.G. 1991. Organizational Behavior in Education. Boston: Allyn and Bacon.

Pidarta, M. 1992. Pemikiran tentang Supervisi Pendidikan. Jakarta: Bumi Aksara.

Sergiovanni, T.J., \& Starrat, R.J.1979. Emerging Pattern of Supervision: Human Perspectives. New York: McGraw Hill Book, Co.

Sergiovanni, T.J. 1982. Supervision of Teaching. ASCD. 